Essigsäure reguliert. Strontiunmitrat wurde zugesetzt. (Dieses bildet schwerlösliche Salze mit Sulfit und Sulfat, während sich seine Dithionit- und Thiosulfatsalze leicht lösen.) Die radioaktive Natriumthiosulfatlösung $\left(\mathrm{S}^{*} \mathrm{SO}_{3}^{2-}\right)$ wurde zugesetzt. Nach einer Stunde wurde die Lösung durch ein Papierfilter in eine Jod-Jodidlösung gegossen. Dabei wurde das Dithionit zu Sulfat oxydiert und fiel als Strontiumsulfat aus, welches abzentrifugiert wurde. Das Zentrifugat wurde mit Bromwasser oxydiert und das gebildete Strontiumsulfat abzentrifugiert. Tabelle 2 gibt die Resultate eines Versuches an.

Tabelle 2.

\begin{tabular}{llr} 
Nr. & $\mathrm{SrSO}_{4}$ aus: & $\begin{array}{r}\text { Impulse/ } \\
\text { Min. }\end{array}$ \\
\hline 1 & Dithionit nach der Separation & 3 \\
2 & Thiosulfat " " & 3 \\
3 & ursprünglichem Thiosulfat & $\mathbf{3 5 2 9}$ \\
& & 4526
\end{tabular}

Aus den Versuchen geht hervor, dass bei $18^{\circ} \mathrm{C}$ in einer Lösung vom $\mathrm{pH}=13$ nach 44 Stunden und in einer Lösung vom $\mathrm{pH}=6$ nach einer Stunde kein Schwefelaustausch zwischen $\mathrm{S}_{2} \mathrm{O}_{3}^{2-}$ und $\mathrm{S}^{*} \mathrm{SO}_{3}^{2-}$ nachgewiesen werden konnte. In einer kommenden $\mathrm{Ar}$ beit soll über das experimentelle Verfahren dieser Arbeit und die Resultate der Untersuchungen über den Austausch zwischen $\mathrm{SS} * \mathrm{O}_{3}^{2-}$ und $\mathrm{S}_{2} \mathrm{O}_{4}^{2-}$ sowie zwischen $\mathrm{O}_{3} \mathrm{~S} * \mathrm{SSS}^{*} \mathrm{O}_{3}^{2-}$ und $\mathrm{SO}_{4}^{2-}$ ausführlicher berichtet werden.

1. Binz, A., und Sondag, W. Ber. 38 (1905) 3830.

2. Kurtenacker, A., Mutschin, A., und Stastny, F. Z. anorg. u. allgem. Chem. 224 (1935) 410.

3. van der Heijde, H. B. Rec. trav. chim. 72 (1953) 95.

Eingegangen am 7. Juli 1953.

\section{Rate of Ringclosure in the Edman Method}

\section{B. DAHLERUP-PETERSEN}

Chemical Department, Carlsberg Laboratory, Copenhagen, Denmark

Tn the course of investigations carried lout at the Carlsberg Laboratory on the Edman method for stepwise breakdown of peptides, the rate of ringclosure with formation of thiohydantoin was studied for a series of different compounds:

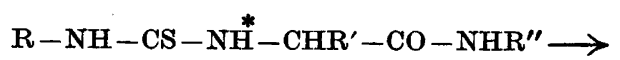

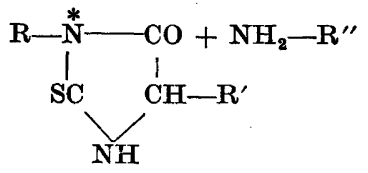

$\mathbf{R}$ being methyl-, $a$-naphthyl-, $p$-methoxyphenyl-, phenyl-, $o-, m-, p$-nitrophenyl. The method used was that described by Dahlerup-Petersen, Linderstrøm-Lang, and Ottesen ${ }^{1}$, this method having the advantage that the thiohydantoin, which is relatively unstable in aqueous solutions, is removed continuously by benzene, in which it is very soluble. Experiments have shown that the rate of hydantoin formation is slow as compared to that of extraction under the given conditions 1 and that therefore the rate at which the hydantoin appears in the benzene is a reasonably quantitative measure of the rate of ringclosure. Table 1 shows the monomolecular rate constants obtained for the reaction at $70^{\circ} \mathrm{C} \pm 1^{\circ}$ in $\mathrm{pH} 4.5$ (at $20^{\circ}$ ) $0.05 N$ citrate buffer, concentration of thiourea compound 0.02 molar.

Table 1.

$$
\begin{array}{cc}
\mathbf{R}^{\prime}=\mathrm{CH}_{3} & \mathbf{R}^{\prime}=\mathbf{H} \\
\mathbf{R}^{\prime \prime}= & \mathbf{R}^{\prime \prime}=
\end{array}
$$
$\mathrm{CH}_{2} \mathrm{CONHCH}_{2} \mathrm{COOH} \mathrm{CH}_{2} \mathrm{COOH}$

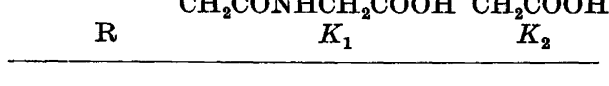

Methyl

0.09

$p$-Methoxyphenyl $\quad 0.13$

$a$-Naphthyl $\quad 0.18$

$\begin{array}{ll}\text { Phenyl } & 0.19\end{array}$

$p$-Nitrophenyl $\quad 0.18$

0.11

$0.18 \quad 0.15$

m-Nitrophenyl $\quad 0.76 \quad 0.25$

$\begin{array}{lll}o-N i t r o p h e n y l & 0.36 & 0.21\end{array}$

It will appear from this table that the rate constants increase with increasing electronegative influence exerted by $\mathbf{R}$ upon the nitrogen marked with an asterisk, the only definite deviation from this rule being the constant for the $O$-nitrocompound. Steric hindrance may play a role here.

1. Dahlerup-Petersen, B., Linderstrøm-Lang, K., and Ottesen, M., Acta Chem. Scand. 6 (1952) 1135.

Received July 11, 1953.

Acta Chem. Scand. 7 (1953) No. 6 